\title{
関西圏の鉄道駅改札内に設置さ れた施設周辺の人間行動特性 一鉄道駅舎の複合化に関する研究（2）- \\ RELATIONSHIP BETWEEN HUMAN BEHAVIOR AND FACILITIES LOCATED IN CONCOURSE OF THE RAILWAY STATIONS IN KANSAI AREA
}

\author{
横田隆司— $* 1$ \\ 伊丹康二— $* 3$ \\ キーワード： \\ 施設配置，店舗，休䄽スペース，立寄り行動， \\ スペースシンタックス理論
}

Keywords:

Facility location, Shop, Lounge, Short visit, Space syntax theory

\section{Takashi YOKOTA $-* 1$ \\ Koji ITAMI $* 3$}

This study aims to clarify human behavior in front of lounge in a concourse of the monorail stations and shops of the railway stations in Kansai area. The data collected from the investigation conducted in 2008 are analyzed from the point of view of human characteristics with space syntax theory. Characteristics of human behavior in front of lounges in a concourse at the monorail stations and shops in the normal railway stations are analyzed. Left-hand and right-hand circular direction on the way to ticket wicket were also found. Finally, technical proposal on planning facilities located in concourse are discussed.

\section{1. はじめに}

近年, 様々な規模の駅において複合化が進み, 改札外のみならず 改札内の空間にも店舗が配置されている例が多数見られる。とくに 首都圈では近年, J R 東日本のエキュートにみられる駅ナカ商業施 設が注目を浴びている注1)。著者らは鉄道駅の施設複合化に関する 研究文 1) の継続研究である前報文 2) において, 関西圈の鉄道会社の 駅舎を対象として，施設数の面からに限られるが，改札内にどのよ うな業種の店舗がどのように設置されているのかを明らかにするこ とで，改札内への商業施設導入を含めた今後の駅施設の建築計画に 関する示唆を得た。

本報告はその続報として, 店舗に限らず休㮩スペースなど駅改札 内に設置された施設を対象に, 施設前面の通路空間での人間行動な らびに施設への立寄り行動を調查し, その特性を捉えることで今後 の駅施設の建築計画に関する技術的示唆を得ることを目的とする。

なお，鉄道駅空間内での人間行動に関する最近の研究としては, 木戸ら文3) は駅構内自由通路に設置された商業施設周辺の流動を観 察し店舗への流入を報告しているし, 諏訪ら文4) は店舗周辺での滞 留の発生を明らかにするとともに, 混雑回避のための店舗前スペー スを提案している。ただし,これらの研究は関東圈での調查であり, 本報告が前報文2）と同様, 関西圈の事例を扱っていること, ならび に比較的均質なモノレール駅空間と一般的な駅空間での人間行動の 比較を行っている点に特徵があるものと考えている。

\section{2. 調査方法}

調査は大きく, (1)空中駅のために駅の内部空間が比較的均質な $\mathrm{O}$ モノレール駅における利用実態調查と, (2)一般的な鉄道駅（以下, 一般駅）における利用実態調查からなる。それらの結果から, 駅改 札内の空間構造と利用行動との関係を探る。

（1）モノレール駅舎における休秘スペース利用状沉調查 $\mathrm{O} モ$ ノレール線は，大阪府北部から東部を結ぶ第 3 セクター運営
の跨座式モノレール路線である。駅舎は空中に建設されているもの が大半で類似した空間構成をもつ。調查は各駅に赴き, 改札内コン コースでの施設設置状況を調查した上で，改札内コンコースにおけ る各施設への利用者の立寄り行動や利用状況を観察調查し, 駅の平 面計画上あるいは空間計画上, 施設設置が駅利用者の行動に与える 影響について考察を行う。調查日時は 2008 年 7 月〜 8 月と 2010 年 6 月（追加調查）である。調查時間帯は, 後述する予備調查から, コンコースにおいて待ち合わせ行動など様々な活動が見られ施設利 用行動を観察するのに最も適すると考えた夕刻の時間帯に絞った。

（2）一般的な鉄道会社の駅舎における店舗利用行動調查

（1）と同様の調查を，一般駅として前報で対象とした鉄道会社 の中から, 駅舎の平面図などが得られた $\mathrm{E}$ 社の駅改札内において実 施する。調查日時は 2008 年 11 月〜 12 月で, 改札内コンコースに設 置された店舗の利用状況観察を平日の朝・昼・夜の 1 日 3 回, 一定 時間ずつ観察する。これは, 前報で一部報告した通り，店舗利用が 駅の立地や時間帯によって異なることが予想されたためである。

なお，（1）のモノレール駅では休熄施設を，（2）の一般駅では 商業施設を対象としていることから利用形態は、当然異なる。しか し，モノレール駅舎は比較的余裕のある休憩スペース注 2) を持つ一 方 (図 1 参照)，一般駅舎はそれぞれ異なった内部空間を持つことか ら, それらの比較により単純な空間構造とやや複雑な空間構造での 人間行動の差異への示唆を得ることも本報告の目的と考えている。

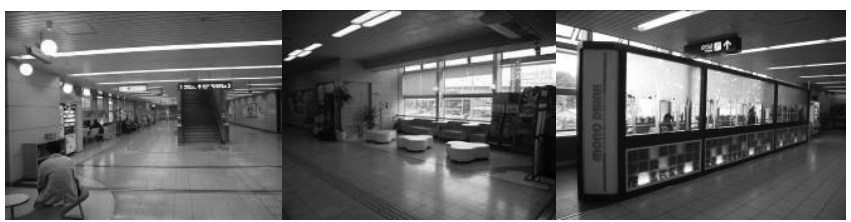

【リニア型：S21 駅】【スペース型:S11 駅】【キュービクル型:S12 駅】 図 1 モノレール駅改札内の休秘スペース
Prof., Graduate School of Eng., Osaka Univ., Dr. Eng.

Lecturer, Graduate School of Eng., Osaka Univ., Dr. Eng. Assistant Prof., Graduate School of Eng., Osaka Univ., Dr. Eng. 


\section{3.モノレール駅構内の休咱スペースと利用者行動の関係}

\section{1 各駅における施設設置状況}

前述のようにモノレールの各駅は規格化されているために空間に 余裕があり，様々な施設が設置されている。その設置施設を示した 表 1 をみると, 改札内には主としてサービス機能や快適性を向上さ せるための機能が設置されていることがわかる。これは，Oモノレ 一ルが経営理念の一つとして「駅リビングプラン」を揭げており, リビングルームのような快適性を取り入れた設備を導入していくと いう計画であるためでもある注3)。本報告では表 1 の休款スペース とその前面空間を＜休嚊スペース $>$ と定義する。

改札口からプラットホームへ向かうコンコース上の通路空間の構 成と休嚊スペースの配置は表 2 のように大きく 3 タイプに分けられ る。乗降客数とタイプの関係はとくに見られない。もちろん，乗換 駅の中には大きく空間が異なる駅もあり，大病院が隣接する 2 駅に は薬局が併設されているなど，若干の相違点はある。

なお，当該会社の企画担当へのヒアリング（調査日 2008 年 6 月 10 日）によれば，このような設置形態になったのは，通路幅がさま ざまな理由で異なることが原因であり，基本的にはどの駅にも同様 に設置していくというのが方針で，乗降人員等をとくに考慮に入れ て設置しているわけではないとのことである。この点は，前報でみ たように一般の鉄道会社が乗降客数を考慮して店舗設置を計画して いるのとは異なっている。

表 1 Oモノレール各駅の設置施設一覧 (2010 年 3 月現在

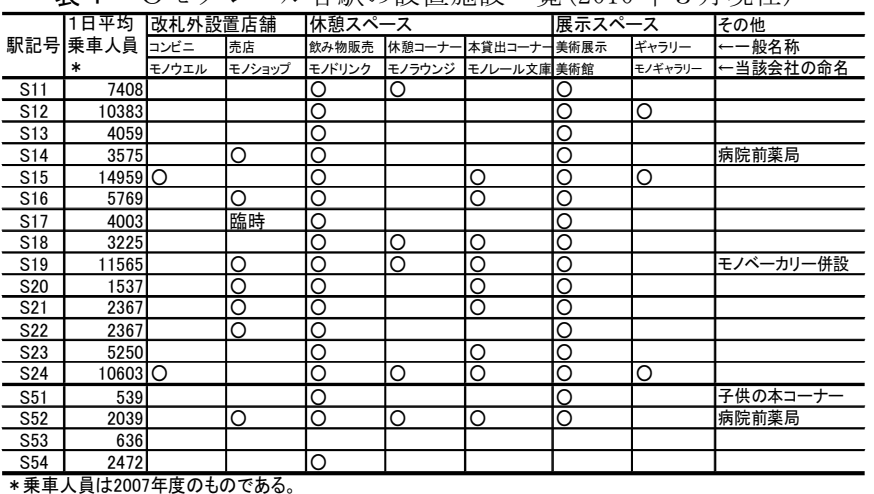

表 2 休憩スペースと通路の構成タイプ

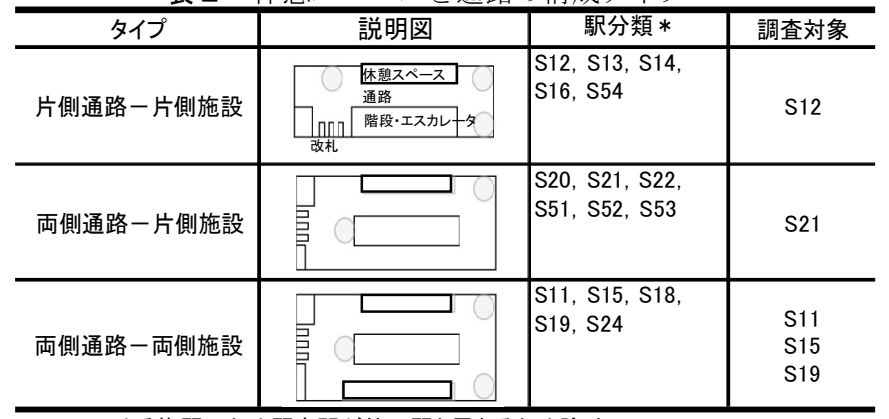

*S17,S23は乗換駅のため駅空間が他の駅と異なるため除外。

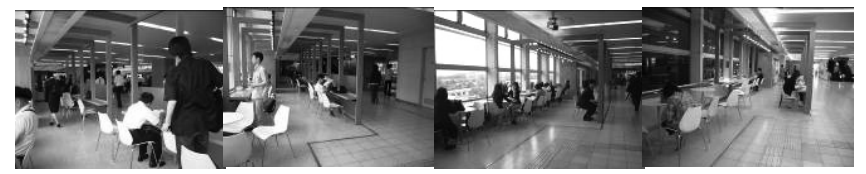

【8:00】【12:00】【16:30】 【19:30】

図 2 モノレール駅構内での予備調査の模様（S15 駅）

\section{2 予備調査による休秘スペースでの行動特性}

ここでは休悡スペースを主たる設置施設と考え，その前面通路で の人間行動を考察する。そのためにまず時間帯や調查場所を選定す る上での予備調查として, 調査候補駅 (S15 など) にて 2008 年 6 〜 月（平日）に観察調查を行った。図 2 はその一例の様子である。こ の予備調査より分かったことは以下のとおりである。

a ）休憩スペースでは，飲食する，本を読む，勉強をする，身だし なみを整える, パンフレット類を読む, おしゃべり，待ち合わせ， 携帯メールを見る等のさまざまな行為が見られる。

b ）休悡スペースのタイプ別（図 1 参照）にみると，仕切りをもつ キュービクル型が他のタイプよりも利用者が多い。

c ）休稹スペースでの行為の差異により，行為後にプラットホーム に向かうケースと改札に向からケースに偏りが見られる。

d）昼は乗降客が少ないこともあり休憩スペースの利用も少なく， 朝は利用が多いものの通勤前の飲食等の行動に限られる。

以上の予備調查の結果から, 本調查では休嚊スペースでの行為,

タイプ別の利用のされ方の差異, 行為後の行動を中心に夕方の時間 帯の調査を行うこととした。ただし，トイレ利用・乗り越し精算等 の行動は対象に含めない。なお，図 1 に見られる休憩スペースの内 部空間と滞在行動の関係や, 表 1 にある展示スペースのような新し い試みについては次報で別途，報告する予定である。

\section{3 本調査による休䕀スペースでの行動特性（表 ろ）}

（1）駅改札内コンコースにおける人間行動

乗降客はプラットホームとコンコース間ではエスカレータを利用 する者が大半である。これは手前に階段があっても変わらず，階段 を通り過ぎエスカレータを利用する。ただし, 電車発着時にコンコ 一スが降車客であふれる場合には階段利用者も若干増える。

乗客は電車発着直前の慌ただしい時間帯を除くと，比較的広い通 路空間を各々のペースでコンコースに向かうことが多く，休梸スペ ースへの立寄り行動も多い。また，電車を待つ短い時間を，ホーム ではなくコンコースで過ごし，電車到着のアナウンスを聞いてから ホームに上がる乗客も見られる。

降客の場合，コンコースからエスカレータで降りた後に改札に向 かって左右いずれかの方向に折り返す必要がある駅では，乗客用エ レベータがない方向に曲る者の方が多い(表 3 参照)。エスカレータ や階段の降り口の足元には左右に曲がるよう案内サインが設けられ ているが，上述の特性に反する場合は無視されている。改札までの 途中で休憩スペースへの立寄り行動は乗客と比較すると少ない。

表 3 にはスペースシンタックス理論でのネットワーク指標を併せ て示している。この理論值文 5) は都市内の空間の利用されやすさを 表すとされるが，駅構内がほぼ同じネットワーク空間構造であるに もかかわらず，表 3 からわかるようにプラットホームからエレベー タで降りてきた客の行動は明らかに偏っている。すなわち，本報告 で対象とした駅舎のような比較的小規模な建築空間では，右回り • 左回りのような人間行動の特性が見られることから，それを考慮し ない限りネットワーク指標は有効でないことが示唆される。

（2）通路タイプ別にみた休㮩スペースと人間行動の関係

既述したように大半の駅は同じ空間構造，すなわち階段・エスカ レータを中心とした比較的広い通路空間を持つことから，人の流れ る通路として使われる部分と，通路空間であっても人のたまるスペ 
表 3 Oモノレールの駅構内における利用行動

(*S12 駅は空間構造が違うため図 4 に利用行動のみ示した。)

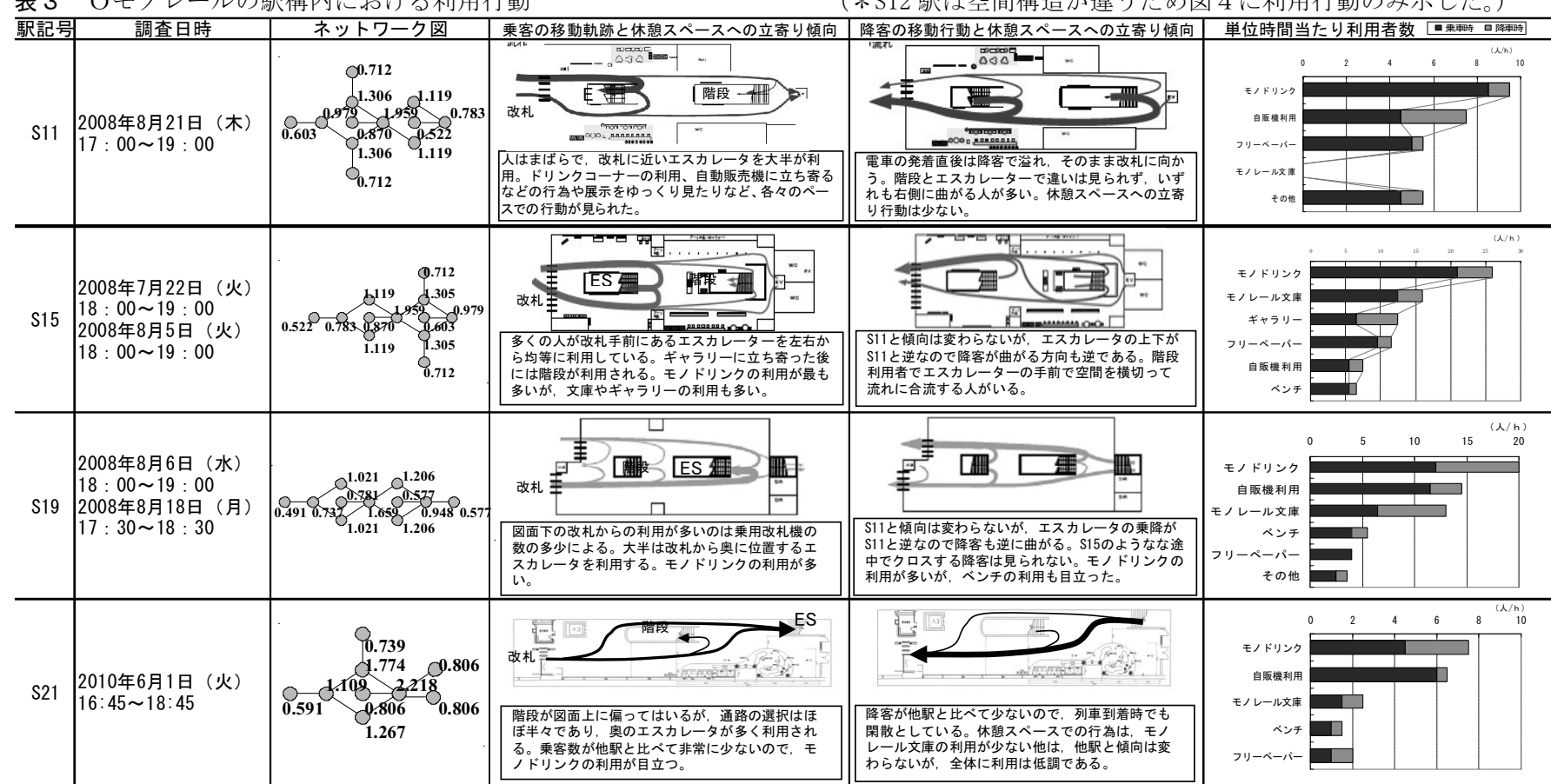

ースとがはっきりと分かれる。このため, 移動行動は他者の立寄り 行動に妨げられることはない。具体的には通路空間の階段寄りに人 の流れる空間が生じ，その外側では少し立ち止まったり歩みを緩め たり寸る光景が，そしてさらに外側でい寸に座ったり本格的に休息

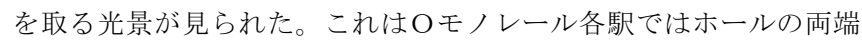
に椅子やアート作品等の機能を持った休款のスペースが設置されて おり,このことが人間行動に対応しているものと推測される。

ただし，例えば S 12 駅のように階段・エスカレータの片側しか通 路がないというように通路空間が限定される場合には，立ち止まる には通路幅が十分でないため，立ち止まり行為は余り見られない。 さらに，キュービクル型の休㮩スペースはコーナーと通路の間には 仕切りがあることから，移動する人間との相互影響は当然のことな がら見られない。

S21 での結果を見る限り，リニア型に設置されている休憩スペー スは個人で利用されることが多い一方で，スペース型は複数人で使 われることが多々見られる。また，ベンチのような荷物を置くこと ができるスペースでは，身だしなみや荷物整理をする者（とくに高 齢者）が散見された。

（3）休㲘スペースでの利用行動

図 3 は調査で得られた各駅における立寄り行動の単位時間当たり

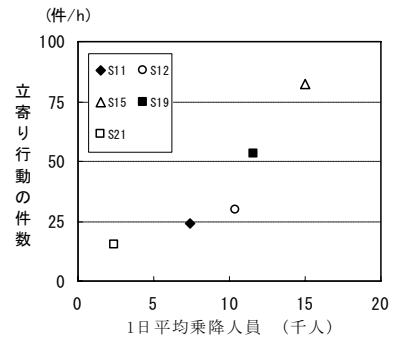

図3 乗降人員と立寄り 行動の関係

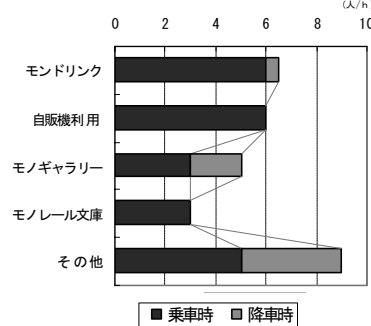

図 4 S12 駅での利用行動 (2008 年 7 月 16 日 (木)
の件数と乗降人員の関係を表したものである。この結果と各駅がほ ぼ規格化された同じ空間構造をもつことより，乗降人員すなわち通 路を通過する人員の大小と立寄り行動の件数が相関していることが 推測される。

表 3 と図 4 に示す休数スペースの利用行動をみると, いずれの駅 においてもモノドリンク注4) の利用が自販機利用と併せて多いこと が傾向として読み取れる。ただし，モノレール文庫注5) やモノギャ ラリーの利用行為も, 駅によってはモノドリンクの 5 割以上の利用 があり，そのほかの行為と比べて著しく少ないわけではない。特に モノレール文庫は比較的高齢者層の利用があることが観察調査によ ってわかった。

（4）立寄り行動前後の行動

ベンチや自動販売機コーナーは改札からプラットホームへ向かう 乗客の利用が多い。一方，ギャラリーやモノレール文庫のように移 動途中とは関係ない鑑賞や図書借り出しという趣味的な行動は，乗 客・降客いずれも観察される。また, 高齢者の行動に注目すると, 改札からベンチに至り，そこで物を置いて休熄した後，それからプ ラットホームへ移動するケースが数例観察された。

\section{4. 一般駅改札内での店舗前空間と利用者行動の関係}

前報では改札口と店舗位置との関係について, 駅立地や利用時間 帯などの要因を含めて考察した。しかし，3 事例と少数事例であっ たことから，ここではさらに事例を加えて計 13 事例について, 利用 客の属性，店舗の属性，さらには店舗前通路空間の属性について 3 章の休覟スペースとの差異も含めて検討を行う。

\section{1 利用客の属性からみた店舗利用行動特性}

平日の各駅の利用実態調查の記録を表 4 にまとめる。朝が最も利 用が多く，次いで夕方で，昼間が最も少ないというのが一般的傾向 である。これは, 先に述べたモノレールでの結果と変わらない。

次に図 5 に単位時間当たりの店舗利用者数と乗降人員の関係を示 
す。店舗の利用の多少には乗降人員の多少と関係が見られるものの, その影響は明確ではない。また図 6 左図は, 各駅店舗で見られた利 用行動を乗降客別に示したものである。乗車時の利用者の占める割 合が大きい場合が多いものの, 設置業種やその規模によっては降車 時の利用も多いことがわかる。

\section{2 店舗業種からみた店舗利用行動}

図 5 を業種別にみると売店は利用件数が多く, 和洋菓子等は非常 に少ない等, 業種による特徵がみられる。特に利用件数の多い S6 駅のコンビニは規模も大きく, 立寄り行動の人数が店舗規模と相関 していることが推測される。また, 図 6 右図は時間帯別にみた店舗 利用者の割合である。基本的には朝の時間帯が最も多く, 夕方がそ れに続き，昼間は最も少ないことがわかる。

以下, 表 4 をもとに各店舗の属性を含めて考察する。

（1）売店設置駅 $(\mathrm{S} 1 \sim \mathrm{S} 6)$

調查駅は計 6 駅である。時間帯別の利用傾向は上述の通りで, 都 心と郊外の差異は見られない。調查した駅はいずれも改札の正面に 店舗が配置されているが, 改札から店舗までの距離や, ホーム・改 札へ向かう駅利用客の動線が各駅で少しずつ異なっているので, 店 舗利用者の行動も若干違いが見られる。とくに, S1 駅での対面形式 の売店は, その他の駅でのウォークイン形式の売店と違い通路上に 利用客が滞在することになるが, この駅の場合、店舗前と横に滞在 空間が生じていており、通行上の問題は見られない。

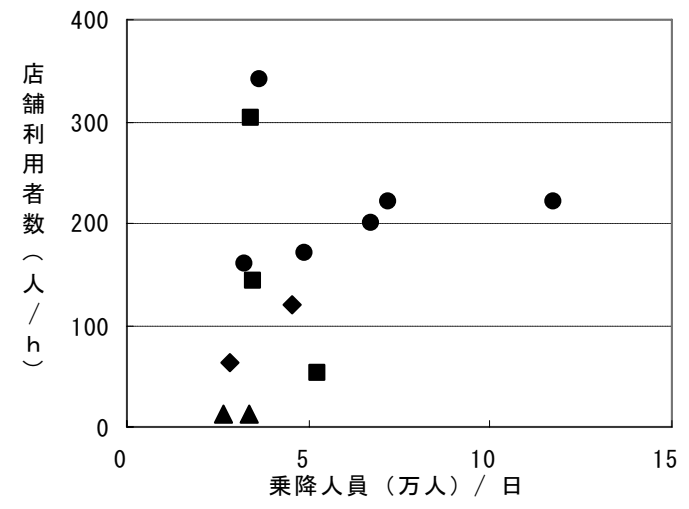

: 売店 $\diamond:$ ベーカリー $\Delta$ : 和菓子 $\mathbf{\square}:$ その他

図 5 利用者数と乗降人員の関係

\section{（2）食品店設置駅（F1〜F4）}

調查駅は計 4 駅である。F1 駅では対面形式のベーカリー, F2 駅で は対面形式のベーカリーに喫茶スペースを設けた店舗が, F3 駅と F4 駅ではそれぞれ対面形式の和洋菓子が設置されている。郊外駅の食 料品の場合 (F1 駅, F4 駅) は降車時の利用が最も多いというように, 売店でのクイック利用を想定しない新しい駅ナカ立地の業種では, 利用時間帯が異なることは前報で述べた通りである。F1 駅と F4 駅

表 4 鉄道駅改札内店舗前の利用行動

\begin{tabular}{|c|c|c|c|c|c|c|c|c|c|c|c|c|c|}
\hline $\begin{array}{l}\text { 駅 } \\
\text { 記 } \\
\text { 号 }\end{array}$ & 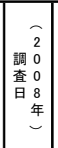 & 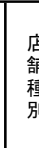 & 客 & \begin{tabular}{|l|} 
店全 \\
形息 \\
対 \\
面 \\
式
\end{tabular} & & $\begin{array}{l}\text { 改札 } \\
\text { 店埔 } \\
\text { 改 } \\
\text { 仧 } \\
\text { 正 } \\
\text { 面| }\end{array}$ & 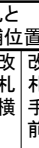 & & $\begin{array}{l}\text { 都郊 } \\
\text { 心 }\end{array}$ & 平面図と立寄り傾向 & 凡例 改札 改札からホー & $\begin{array}{l}\text { 別(朝·昼·タ方) } \\
\text { 利用行動者数 }\end{array}$ & 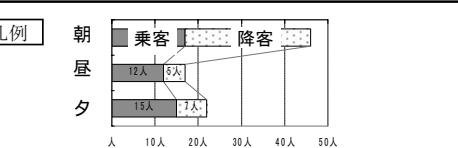 \\
\hline S1 & \begin{tabular}{|l|}
12 月 \\
11 日 \\
(木)
\end{tabular} & & 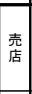 & 0 & & 0 & & & 0 & 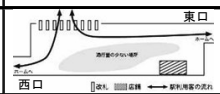 & $\begin{array}{l}\text { 動線から離れた店舗周辺にはペースができてい } \\
\text { る。店舗では新聞や飲食物がよく買われている。 }\end{array}$ & 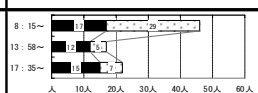 & $\begin{array}{l}\text { 朝は降客、昼・多は乗客の店舗利用が多い。 } \\
\text { 西口・東口共に乗車時の店舗利用が多い。 }\end{array}$ \\
\hline S2 & \begin{tabular}{|c|}
11 月 \\
11 日 \\
( 火)
\end{tabular} & & 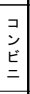 & & O & 0 & & & 0 & & $\begin{array}{l}\text { 平面配置上、乗客は店舗へ入る際に他の駅利用客 } \\
\text { の流れを横切る。一方、降車時の売店利用客はス } \\
\text { ムーズに改札へ向かうことができる。 }\end{array}$ & 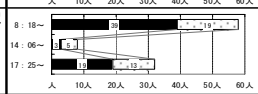 & $\begin{array}{l}\text { 朝の利用がもっとも多い。昼は店舗利用者は } \\
\text { 非常に少ない。タ方も乗車時の店舗利用者が } \\
\text { 多い。 }\end{array}$ \\
\hline S3 & $\begin{array}{l}11 \text { 月 } \\
28 \text { 日 } \\
\text { (金) } \\
\end{array}$ & 売 & 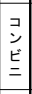 & & 0 & 0 & & & 0 & & $\begin{array}{l}\text { S2とは逆に、乗客は店舗へ直に向かうことができ } \\
\text { る。また22より舗幅か広いので立寄りやすい。立 } \\
\text { 読客も目立つ。 }\end{array}$ & 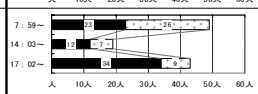 & $\begin{array}{l}\text { 朝の店舗利用客が多い。ただしホーム上にも } \\
\text { 店舗があるたか、降客の利用も多い。昼の } \\
\text { 店舗利用客も多い。 }\end{array}$ \\
\hline S4 & $\begin{array}{l}11 \text { 月 } \\
\text { 28日 } \\
\text { (金) }\end{array}$ & 店 & 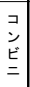 & & 0 & 0 & & & 0 & & 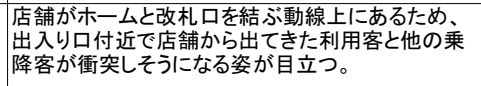 & 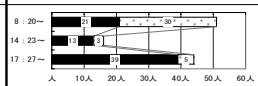 & $\begin{array}{l}\text { 朝は乗客・降客の利用がほぼ半々であるが、 } \\
\text { 昼・タでは車時の利用が多い。 }\end{array}$ \\
\hline S5 & \begin{tabular}{|l|}
11 月 \\
5 日 \\
(水)
\end{tabular} & & 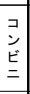 & & 0 & 0 & & & 0 & $\sqrt{\frac{10}{\sqrt{2}}}$ & 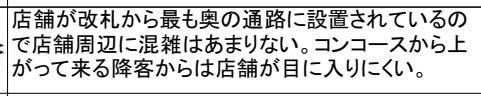 & 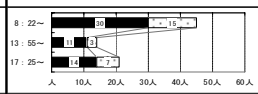 & $\begin{array}{l}\text { 朝の利用客数が最も多く、昼・舛は大きな } \\
\text { 変化がない。朝タとも店舗前に人だかりがで } \\
\text { きることはない。 }\end{array}$ \\
\hline S6 & $\begin{array}{l}11 \text { 月 } \\
14 \text { 日 } \\
\text { (金) }\end{array}$ & & 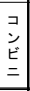 & & 0 & 0 & & & 0 & & $\begin{array}{l}\text { 利用客数が非常に多く、その属性も幅広いのは、店 } \\
\text { 舗の規模が大き品揃えも豊である゙て理由と } \\
\text { して考えられる。 }\end{array}$ & 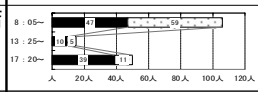 & 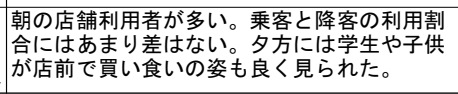 \\
\hline $\mathrm{F} 1$ & \begin{tabular}{|l|}
11 月 \\
5 日 \\
(水)
\end{tabular} & & $\begin{array}{l}0 \\
i \\
\text { z } \\
1 \\
1 \\
1\end{array}$ & 0 & & 0 & & & 0 & & $\begin{array}{l}\text { ベーカリーという店舗の性質上、比較的乗降客が少 } \\
\text { ない昼間も利用がある。とに郊外駅のため夕方、 } \\
\text { 降車時に立寄りが多く見られた。 }\end{array}$ & 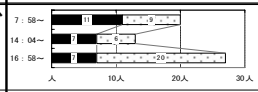 & $\begin{array}{l}\text { 朝の駅利用客数は多いが、タ方の方が多い傾 } \\
\text { 向がある。方時には店埔前に電車 } \\
\text { 到着時には人だかりができる。 }\end{array}$ \\
\hline F2 & $\begin{array}{l}11 月 \\
11 日 \\
(火) \\
\end{array}$ & 食 & 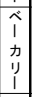 & 0 & & & 0 & & 0 & & $\begin{array}{l}\text { 降車側の動線のすぐ横に店舗があるため降客が } \\
\text { 多い場合には埔に近づくのは非常に難しい。喫 } \\
\text { 茶ブースもあまり利用されていはい。 }\end{array}$ & 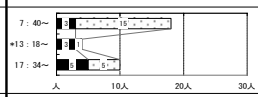 & $\begin{array}{l}\text { 乗降分離の影響が朝の利用状況で明確にわか } \\
\text { る。昼にには駅利用客数は少ないので店埔が片 } \\
\text { 側にあるととう郎はなな条件も特に影はな。 }\end{array}$ \\
\hline F3 & $\begin{array}{l}11 \text { 月 } \\
28 \text { 日 } \\
\text { (金) }\end{array}$ & 店 & \begin{tabular}{|l} 
菓 \\
居 \\
\end{tabular} & 0 & & & & o|c & 0 & & $\begin{array}{l}\text { 菓子店でかつ駅利用者が少ないことから、店舗利 } \\
\text { 用客も少ない。壁面に埋め込まれているため視界 } \\
\text { にりりにいということ要因と考えられる。 }\end{array}$ & 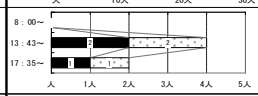 & \begin{tabular}{|l} 
昼には店舗に目をやる人も見られるが、利用 \\
客は少ない。夕方はさらに利用者が少ない。
\end{tabular} \\
\hline $\mathrm{F} 4$ & \begin{tabular}{|l|}
12 月 \\
11 日 \\
(木)
\end{tabular} & & $\begin{array}{c}\text { 菓 } \\
\text { 居 } \\
\end{array}$ & 0 & & 0 & & & 0 & & $\begin{array}{l}\text { F3と同じ業者の店舗である。店舗の形式·配置は } \\
\text { F1に似ているが、Fろと同様、全体として店舗利用 } \\
\text { 客が非常に少ない。 }\end{array}$ & 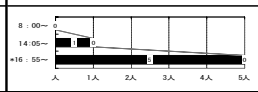 & $\begin{array}{l}\text { 昼の利用はわずかであった。タ方には降車客 } \\
\text { が多くなるが店埔利用客は少なく、すべて乗 } \\
\text { 車客であった。 }\end{array}$ \\
\hline 01 & $\begin{array}{l}11 \text { 月 } \\
25 \text { 日 } \\
\text { ( 火) }\end{array}$ & & $\begin{array}{l}\text { 飭 } \\
\text { 食 } \\
\text { 店 } \\
\end{array}$ & & 0 & & 0 & & 0 & 焉部 & $\begin{array}{l}\text { 改札横に設置されていることから、乗客が動線を横 } \\
\text { 切って店舗に入る姿はほとんど見られない。和は埔の } \\
\text { 利用客はあまり多くない。 }\end{array}$ & 7: & $\begin{array}{l}\text { 朝の店舗利用客は少ない。2店舗が隣接して } \\
\text { いるが、朝・昼・タと利用者は片方に偏って } \\
\text { いる。 }\end{array}$ \\
\hline $\mathrm{O} 2$ & \begin{tabular}{|l|}
$11 月$ \\
$25 日$ \\
$(火)$
\end{tabular} & $\begin{array}{l}z \\
\text { の } \\
\text { 他 }\end{array}$ & & 0 & 0 & & 0 & & 0 & $\sum^{20}$ & $\begin{array}{l}\text { 昼夕のみ図右の改札口が開放されているが、乗降 } \\
\text { 客が朝ほど多くないため、交差流は問題にはならな } \\
\text { い。 }\end{array}$ & 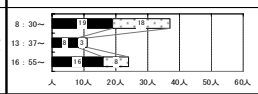 & $\begin{array}{l}\text { 朝は学生のコンビニ利用が多いが、店舗前に } \\
\text { は十分なスペースがあるので問題にはならな } \\
\text { い。 }\end{array}$ \\
\hline 03 & \begin{tabular}{|l|}
12 月 \\
12 日 \\
(金)
\end{tabular} & & $\begin{array}{l}\text { 書 } \\
\text { 占 }\end{array}$ & & O & & $c$ & o| & 0 & (2) & $\begin{array}{l}\text { 改札から入って見えにくいが利用者は多い。書店な } \\
\text { ので乗換の利用客の時間つぶしに使われているこ } \\
\text { とも要因と思われる。 }\end{array}$ & 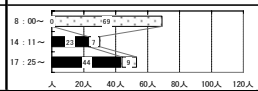 & $\begin{array}{l}\text { 朝も書店の利用は多い。昼は乗客・乗換客の } \\
\text { 立寄りが多い。多には降客が時の障害 } \\
\text { となるが、それでも店舗の利用客は多い。 }\end{array}$ \\
\hline
\end{tabular}




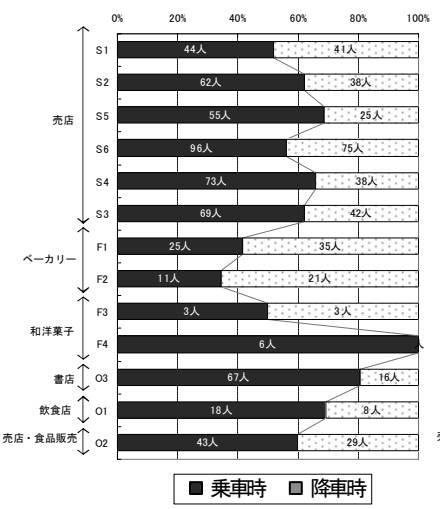

【乗降別の割合】

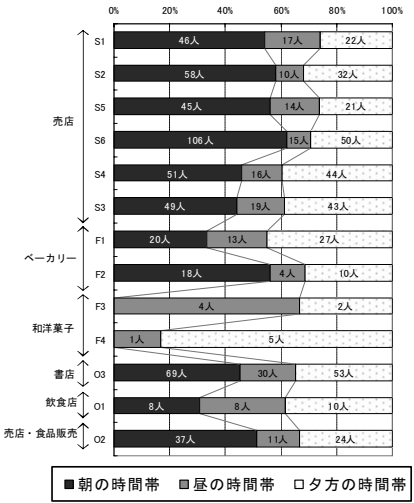

【時間帯別の割合】
図 6 業種別に見た店舗利用行動

では店舗が改札の正面に配置されており，そのためか利用は多い。 一方, F2 駅では改札を手前側としてコンコースの横手に, F3 駅では 手前側に配置されていることから客の利用勝手は良くない。

（3）その他業種の設置駅（01〜03）

調查駅は計 3 駅である。時間帯別の傾向は上述の通りであり, 都 心と郊外という差異も見られない。02 駅ではウォークイン形式の売 店と対面形式の食品販売店が, 02 駅の夕対面式の売店が設けられて いるが，売店とプラットホームへの移動客の間にうまくスペースが 生じており問題は見られない。01 駅と 02 駅ではいずれも改札を手 前として横側に 2 店舗が隣接して配置されているが, 改札からホー ムまでの駅利用客の動線との関係は多少異なっている。03 駅では手 前側に店舗が配置されているが, 分岐駅でありホーム数が多く, 駅 利用客の動線との関係は複雑である。

\section{3 店舗前通路空間の属性からみた店舗利用行動}

(1) 店舗形態による差異

以上見たように, 対面式店舗が改札横にあって移動客と交錯して いる場合には, 店舗利用者との交錯が懸念される。しかし, 店舗位 置が移動通路上になければうまくスペースが生じて問題はない。逆 に, 交錯してしまうと店舗利用者と移動客が混じってしまうケース も見られる。

（2）改札と店舗位置との関係からみた行動特性

前報告では, 食料店の 3 事例（F1, F2, F3）に限られるが, 改札と の位置関係（改札正面, 同側面, 同隣接）が利用行動と密接な関係 があることを示唆した。今回追加した 9 事例を含めて表 4 から考察 すると, 売店においても食料品と同じ事が言える。すなわち, <改 札正面>に店舗が立地すると, 利用客の店舗へのアクセスが容易で あると同時に, 店舗の前には利用客の滞留するスペースができると いうメリットがみられる。<改札側面>はその他の業種に限られる が, やはり客動線が交錯していることが読み取れる。<改札隣接型 >はF3の菓子店では利用が少ないが, 03 の書店では利用が多いこ とから, 前報で問題視した “改札から店舗が見えにくい”という問 題は，業種別に異なることが示唆される。

以上を整理すると, 店舗立地としては, 対面式で店舗前に客たま りを必要とする業種の場合, <改札正面 >が商業立地として望まし い一方, 一般の状況客と交錯するような＼cjkstart改札側面＞は避けるべき であると言える。＜改札隣接＞は＜改札正面＞よりは駅利用からの
表 5 店舗設置位置とプラットホームとの関係

\begin{tabular}{|c|c|c|c|c|}
\hline タイプ名 & 直進型 & 二方向分岐型 & 四方向分岐型 & 乗り換え型 \\
\hline 説明 & $\begin{array}{l}\text { 改札からプラッ } \\
\text { トホームまで直 } \\
\text { 進するタイプ }\end{array}$ & $\begin{array}{l}\text { プラットホーム } \\
\text { に向けて二方向 } \\
\text { に分かれている } \\
\text { タイプ }\end{array}$ & $\begin{array}{l}\text { ブラットホーム } \\
\text { ヘ四方向に枝分 } \\
\text { かれするタイプ }\end{array}$ & $\begin{array}{l}\text { コンコース上で } \\
\text { 別の路線に移動 } \\
\text { するタイプ }\end{array}$ \\
\hline 該当する調査駅 & $F 2,01$ & $\mathrm{S1}, \mathrm{S} 2, \mathrm{~S} 3, \mathrm{~F} 3,02$ & S4, S5, S6, F1, F4 & 03 \\
\hline 事例 & $\lim _{\frac{1}{2}}^{\frac{1}{2}}$ & 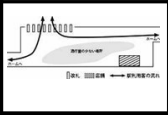 & & חow \\
\hline $\begin{array}{l}\text { 通路内歩行者から } \\
\text { の見え方 }\end{array}$ & $\begin{array}{l}\text { 乗降方向と店舗 } \\
\text { の位置関係で見 } \\
\text { え方は異なる }\end{array}$ & $\begin{array}{l}\text { 進行方向と店舗 } \\
\text { 位置の関係で見 } \\
\text { え方が異なる }\end{array}$ & $\begin{array}{l}\text { 進行方向と店舗 } \\
\text { までの距離によ } \\
\text { り見え方が異な } \\
\text { る }\end{array}$ & $\begin{array}{l}\text { 移動歩行と店舗 } \\
\text { 位置との関係で } \\
\text { 見え方は異なる }\end{array}$ \\
\hline
\end{tabular}

視線にやや問題があるものの危惧するほどではないことが示され， おおむね前報の結果が追認されたと考える。

（３）プラットホームと店舗位置の関係からみた行動特性

ここでは, 表 5 に示す店舗設置位置とプラットホームとの関係で 分析を試みる。すなわち（2）は乗客が改札から入った場合を主と して想定しているのに対し，ここでは降客がプラットホームからコ ンコースに移動してくることを想定した検討とみなせる。

a ) 直進型

これはプラットホームから改札まで一直線に通路がつながってい るタイプであり，（2）の<改札側面>と同様に，乗降客のいずれか と店舗利用者が交錯してしまう。

b ）二方向分岐型

二方向に分離することから，改札正面にある場合はともかく，い ずれかに店舗が偏ると乗降客の動線から離れてしまう。たとえば S1 において店舗前面は降客が多い通路となっているため, 電車到着時 は降車客の通行量が多く, 店舗前には近づきにくい。ただし, その 他の時間帯では問題はみられない。

c）四方向分岐型

b ）の二方向分離型と基本的には同じで, 店舗前に人の滞留する スペースができていることで移動客との分離が容易なタイプである。 ただし, 改札から距離があると手前でプラットホームに向かう場合 には不便になる。

\section{d）乗り換え型}

03 駅の店舗は複数のプラットホームを移動するために跨線橋上 に設置されている事例である。これは, 直進型と同様, 列車到着時 には降客がコンコースにあふれてしまうと店舗利用者との交錯が生 じるので問題であるが，それ以外の時間帯では問題はみられない。

\section{(4)まとめ}

以上の結果を駅舎が規格化されているOモノレールと比較すると, (1)立寄り行動の人数は駅の乗降人員と相関関係がある, (2)立寄り行 動は, 降車時よりも乗車時に多く見られることが共通点として挙げ られる。その一方で $\mathrm{E}$ 社の一般駅では, (3)立寄り行動の件数は, 乗 降人員だけではなくその他の様々なファクターからの影響を受ける 注 6), (4)店舗業種やその規模により, 降車時の立寄りも多く見られ る点は異なる。このように一般駅においては, 駅利用客の行動はよ り複雑であると推測され, 駅舎の形式・店舗の存在により駅利用客 の行動が変化すると考えられることから，店舗を計画する場合は, さまざまな要因を予見することが望まれる。 


\section{5. 結論}

以上, 本報告では駅改札内に設置された休鄎施設や商業施設の利 用行動やその周辺での人間行動の解明を目的として, 主として立寄 り行動の実態調查を行った。以下にまとめを示す。

(1) 一般的な傾向

a ）休㮩施設にせよ商業施設にせよ利用時間帯別にみると, 平日に おいては昼間の利用が最も少ないこと, 朝は朝食など限られた行 動が見られること, 夕方が一日の中で最も利用が多く, かつ施設 周辺での行為の種類も多いことがわかった。

b ）業種によっては例外が認められるが, 改札内施設利用は降車時 よりも乗車時に多く見られた。降車時はコンコース内に人が集中 し,ほとんどの人が流れに沿って立ち止まることなく歩いていた。 c ）高齢者の行動については, 定性的ではあるが改札を通過した時 点あるいはプラットホームから降りてきた時点で, ベンチに荷物 を置いて休息する様子がみられた。つまり, ベンチが座るという 行為だけでなく, 高齢者の歩行行動を支援する設備としての効能 があることが示唆された。

(2) Oモノレール駅について

a ） Oモノレールの駅舎という空中に設けられ，かつ規格化された

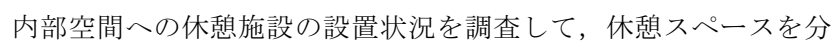
類した上で、休鄎スペースと通路の構成を考察した。

b ）その休款スペースへの立寄り行動を現地調査により，右回り・ 左回り, あるいはサインへの追従という利用者の行動特性が観察 された。つまり, 空間構造がネットワークとして単純であるから といって, 必ずしも人間行動が均質な空間構造に対応しているわ けではないことを示した。

c ）休䕀スペースへの立寄り行動は, 立寄り行動の件数自体は少な いものの乗降人員という駅規模の大小に応じて増減していること を明らかにするとともに, 通路空間の幅や空間構造も立寄り行動 の件数の多少に関係していることを示唆した。

(3) E 社一般駅について

a ）商業施設への立寄り行動については，駅の乗降人員だけでなく 当該施設の業種・店舗形態などがその利用人数の多少に関係して いることを示唆した。

b ）店舗前に客の滞在空間が必要な業種では，店舗前の通路空間と の関係で利用行動が制約される場合があることを指摘した。これ は, 関東圈における調査文 4 ) においても店舗前の店舗利用者によ る乗降客の流動に滞留や歩行速度の低下が見られることと符合寸 る結果である。

c ）店舗設置位置と改札やプラットホームとの関係をタイプ分けし た上で，コンコース内の店舗設置可能空間との関係で人間行動を 慎重に考慮すべき点があることを指摘した。

以上, さまざまな観点から駅改札内の休鄎施設あるいは商業施設 周辺における立寄り行動の特性を明らかにすることができ, 今後の 駅複合化に関する技術的示唆を得ることができたと考える。ただし， 一般駅での店舗利用状況から, 乗降客数に加えて複雑な空間構造と 施設業種が関与しているという示唆が得られたが，調査数が少ない ことからさらに調查事例を増やしてモデル化を追究す心゙きと考える。 その他の今後の課題としては, 本報では平日の調查結果を示したに 過ぎないため, 休日との差異の検証がまず必要となる。また, 高齢
者については観察調査から得られた定性的記述に留まっており，高 齢者や障碍者の利用行動についても, さらに追究することが求めら れよう。

なお次報では, 設置施設内の滞在行動についてより詳細に分析す るとともに, 展示スペースのような新しい試みに対する人間の鑑賞 行動について報告する予定である。

最後になりましたが図面提供など調查に際し多大な御協力を頂い た関係鉄道会社の各位に心から謝意を表します。また，本研究のデ 一タ収集にあたっては, 当時大阪大学大学院の伊達恵氏（現コクヨ (株)，旧姓笹谷）の修士論文に多くを負っており感謝する次第であ る。

注

1)最近の新聞報道（朝日新聞 2010 年 6 月 6 日朝刊）においても, 関東圈の 鉄道各社における駅ナカ施設の競争激化が報じられている。

2)休款スペースは，図 1 にあるように通路空間の空際に机やベンチなどを一 列に並べた【リニア型】，通路空間とは別に休憩用のスペースとして確保 している【スペース型】，さらに仕切り壁を設けている【キュービクル型】 に分けられる。

3)Oモノレールが実施した利用者へのアンケート調查 (2009 年 11 月 26 日実 施）結果によると，さまざまな評価項目の中で「駅のコンビニ・売店・ベ 一カリーは気楽に利用でき, 便利である」という項目の満足度は他の項目 と比較して高くない。

4)ここでは，ドリンクコーナにある自販機で単に飲み物を買う行為をく自販 機利用 $>$ とし，ドリンクコーナーに滞在する行為をくドリンクコーナ $>$ 利 用として別タにカウントしている。

5)モノレール文庫とは，利用者などからの寄贈された書籍を手続きすること なく自由に貸出・返却できるシステムで運営される図書コーナーである。

6)サンプル数が 13 なので分析の妥当性に課題があるが, 表 4 にある<店舗種 別 $><$ 店舗形態 $><$ 店舗位置 $><$ 都心 $\cdot$ 郊外の別 $>$ と <乗降人員 $>$ の 5 力 テゴリーを説明変数, 店舗利用者総数を目的変数として数量化一類で分析 すると, <店舗形態 $>$ の偏相関係数が最も高<, 以下， <店舗位置 $><$ 店 舗種別 $><$ 乗降人員 $><$ 都心・郊外の別 $>$ の順となり，乗降人員の影響は 確かに低い。

\section{参考文献}

1)横田隆司, 柏原士郎, 吉村英祐, 阪田弘一：鉄道駅構内における地域施設 の複合化実態と鉄道駅への施設成立可能性の評価モデルに関する研究，日 本建築学会計画系論文集, No.538, pp.117-123, 2000.12 2)横田隆司，飯田匡，伊丹康二 : 関西圈の鉄道駅における改札内店舗設置の 実態一鉄道駅舎の複合化に関する研究 $(1)$ - , 日本建築学会技術報告集, Vol.34, pp.1087-1092, 2010.10

3)木戸秀一, 保坂秀人, 池辺健志 : 店舗併用型自由通路の利用実態に関する 研究, 日本建築学会大会学術講演梗概集 E, pp.717-718, 2009

4) 諏訪正浩，中村彩子，佐野友紀 ほか 3 名：鉄道駅の利用者行動からみた ラッチ内店舗施設計画に関する考察, 日本建築学会大会学術講演梗概集 $\mathrm{E}$, pp.797-798, 2009

5)Bill Hillier, Julienne Hanson : The social logic of space, Cambridge University Press, 1984

[2010 年 6 月 17 日原稿受理 2010 年 9 月 1 日採用決定］ 